\title{
Naturalne przewietrzanie i komfort termiczny w budynkach użyteczności publicznej
}

\author{
Joanna Pieczara \\ e-mail:jpieczara@jtp-projekt.pl \\ Wydziat Architektury, Politechnika Warszawska
}

\begin{abstract}
Streszczenie. System wentylacji ma wpływ zarówno na występującą w budynku jakość powietrza, jak i na panujący w nim komfort termiczny. Jakość powietrza i klimat wewnętrzny oddziaływają na zdrowie i samopoczucie użytkowników budynków. Użytkownicy preferują budynki przewietrzane w sposób naturalny. Koszty eksploatacji takich budynków są niższe niż budynków przewietrzanych mechanicznie, jednak ich koszty inwestycyjne mogą być większe. Budynki użyteczności publicznej mogą być przewietrzane w sposób naturalny, jednak związane jest to z wieloma ograniczeniami. Podstawową zasadą stosowaną w budynkach przewietrzanych naturalnie jest ograniczenie w nich zysków ciepła i występujących w powietrzu szkodliwych substancji oraz stosowanie materiałów i konstrukcji o dużej pojemności cieplnej i higroskopijnych.

W budynkach przewietrzanych naturalnie, nie zawsze jest możliwe zachowanie stałej temperatury i innych parametrów powietrza, dlatego raczej nie jest możliwe stosowanie jej w budynkach i jego częściach, w których parametry te muszą być zachowane w sposób ciągły. Przewietrzanie naturalne wymaga zastosowania tzn. „adaptacyjnego modelu komfortu termicznego", który uwzględnia warunki panujące na zewnątrz i adaptację użytkowników. W klimacie umiarkowanym systemy wentylacji w budynkach efektywnych energetycznie, muszą pracować, co najmniej w trzech scenariuszach: wiosenno-jesiennym, zimowym i letnim. Systemy wentylacji naturalnej najlepiej funkcjonują w okresach przejściowych. Rozwiązania stosowane zimą, muszą uwzględniać ryzyko strat ciepła powodowanych przez nawiewane zimne powietrze. Natomiast latem problemem może być zapewnienie ciągłości działania systemu wentylacji naturalnej i ochrony budynku przed przegrzewaniem się. Ze scenariuszem letnim związane są systemy nocnego chłodzenia, których skuteczność zależy od ograniczenia zysków ciepła występujących w budynku, jego pojemności cieplnej oraz temperatury nocnego powietrza.

Budynek przewietrzany naturalnie wymaga zastosowania rozwiązań przestrzennych, konstrukcyjnych i funkcjonalnych, które nie mogą pozostawać jedynie w gestii projektanta jednej branży. Dlatego ich projekt wymaga projektowania zintegrowanego, w którym będą brali udział projektanci wielu branż już od fazy wstępnej koncepcji. To wymaganie wraz z innymi ograniczeniami i wyższymi kosztami inwestycyjnymi powoduje, że inwestorzy często decydują się jednak na systemy mechaniczne lub hybrydowe.
\end{abstract}

Słowa kluczowe: system wentylacji naturalnej, komfort termiczny, budynki użyteczności publicznej, efektywność energetyczna, chłodzenie nocne, scenariusze działania wentylacji, pojemność cieplna budynku.

\section{Wprowadzenie}

W klimacie umiarkowanym większość czasu spędzamy w budynkach, dlatego występujące w nich jakość powietrza i klimat wewnętrzny mają wpływ na nasze zdrowie i samopoczucie. Zarówno jakość powietrza jak i komfort termiczny, w dużej mierze zależą od skuteczności i sposobu działania systemu wentylacji, który poprzez dostarczanie świeżego i usuwanie zużytego powietrza, wpływa na jego skład chemiczny, temperaturę i prędkość. Dlatego nieprawidłowo działający system wentylacyjny, który nie zapewnia odpowiedniej wymiany powietrza w budynku, może przyczyniać się do powstawania wielu problemów zdrowotnych oraz obniżać odczucie komfortu termicznego. Do chorób związanych ze złym klimatem wewnętrznym należą tak poważne choroby jak astma, nowotwory powodowane przez radon, ozon, LZO (lotne związki organiczne) 
i inne związki chemiczne zawarte w powietrzu, alergie, problemy z oddychaniem... [1] Natomiast od parametrów powietrza wewnętrznego, takich jak jego temperatura, wilgotność i prędkość zależy poziom odczuwanego komfortu termicznego [2].

Obecnie, po dekadach przewietrzania budynków użyteczności publicznej najczęściej jedynie w sposób mechaniczny, ponownie zaczyna być stosowana wentylacja naturalna bądź hybrydowa. Trend ten występuje najczęściej w tzn. budynkach „zielonych” i po części może wynikać z mody oraz ogólnej tendencji preferowania rozwiązań bliższych naturze. Z drugiej jednak strony przewietrzanie budynku w sposób naturalny, czasami przynosi konkretne korzyści. Badania pokazują, że użytkownicy preferują naturalne systemy wentylacji zwłaszcza, jeśli mogą je sami kontrolować. Ta preferencja występuje nawet wówczas, gdy poziom parametrów komfortu klimatu wnętrza przewietrzanego naturalnie, jest niższy niż w budynkach przewietrzanych jedynie w sposób mechaniczny [1]. Statystyki podają także, że w budynkach przewietrzanych naturalnie, pracownicy rzadziej chorują [3]. Kolejną zaletą systemów wentylacji naturalnej jest to, że w procesie eksploatacji zużywają one mniej energii, zwłaszcza energii elektrycznej, niż systemy mechaniczne. Wg. poradnika dla inwestorów, przygotowanego przez amerykańską organizację Center for Building Performance and Diagnostics oszczędności te mogą wynosić 47-79\%, w porównaniu do poziomu zużycia energii przez system wentylacji mechanicznej [3]. Czy jednak systemy wentylacji naturalnej są zawsze w stanie zapewnić odpowiednią jakość powietrza i klimatu wnętrza? I dlaczego mimo ich wielu zalet, inwestorzy często decydują się jednak na zastosowanie mechanicznych sposobów przewietrzania budynków, zwłaszcza w naszym kraju. Artykuł ten będzie próbą odpowiedzi na te pytania.

\section{Zadania wentylacji}

Zarówno w budynkach użyteczności publicznej jak i w budynkach mieszkaniowych, do głównych zadań każdego systemu wentylacji należy usuwanie z budynku:

nadmiernych zysków ciepła,

- pary wodnej,

- szkodliwych substancji, a zwłaszcza lotnych związków organicznych (LZO) zawartych w elementach wyposażenia wnętrza,

nadmiernych zysków ciepła,

- dwutlenku węgla,

- radonu i ozonu,

- zapachów i wyziewów wydzielanych prze użytkowników

oraz

- dostarczanie tlenu, w miejsce tlenu zużytego.

Systemy wentylacji poprzez nawiewanie świeżego i wywiewanie zużytego powietrza, powodują, że wewnątrz budynku miesza się powietrze świeże i zużyte, przez co rozrzedza się ilość szkodliwych i nieprzyjemnych substancji w nim zawartych, zmienia się jego wilgotność i temperatura. Z powyższego wynika, że ilość świeżego powietrza, jaką należy dostarczyć do budynku zależy od ilości zysków ciepła, pary wodnej, szkodliwych i nieprzyjemnych substancji, dlatego zmniejszając tę ilość można zmniejszyć także ilość potrzebnego świeżego powietrza. Ma to znaczenie zwłaszcza w systemach wentylacji naturalnej, ponieważ najczęściej występująca w nich różnica ciśnień wynosi ok. 50 Pa, w porównaniu do 100-1000 Pa w systemach wentylacji mechanicznej [4], a więc systemy naturalne są znacznie mniej wydajne. Z tego powodu podstawową zasadą, którą należy zastosować w budynkach przewietrzanych w sposób naturalny, jest ograniczenie wewnętrznych i zewnętrznych zysków ciepła oraz ilości szkodliwych substancji emitowanych przez materiały wyposażenia wnętrza, a także zastosowanie materiałów i konstrukcji będących w stanie magazynować zyski ciepła i parę wodną, które później są uwalniane do wnętrza. 


\section{Zagadnienia związane z komfortem termicznym}

Komfort termiczny jest pojęciem złożonym i jego odczucie zależy od następujących parametrów [2]:

1. Zapewnienia odpowiedniej temperatury powietrza,

2. Zapewnienia temperatury po wewnętrznej stronie zewnętrznych przegród budowlanych, zbliżonej do temperatury powietrza,

3. Zapewnienia względnej wilgotności powietrza w granicach $40-60 \%$,

4. Zapewnienia odpowiedniej wentylacji i prędkości powietrza.

System wentylacji wpływa na trzy z czterech powyższych, podstawowych parametrów komfortu termicznego.

W umiarkowanej strefie klimatycznej zapewnienie komfortu termicznego związane jest z zatrzymywaniem ciepła we wnętrzu budynku zimą oraz z niedopuszczeniem do jego przegrzania się latem, co wymaga złożonych rozwiązań. W innych strefach klimatycznych budynki muszą spełniać tylko jedną z tych funkcji, np. z strefie chłodnej najważniejsze jest zatrzymanie ciepła wewnątrz budynku, a w strefie gorącej niedopuszczenie do jego przegrzania.

W krajach Unii Europejskiej zagadnienia związane z komfortem termicznym reguluje norma EN ISO 7730, w Wielkiej Brytanii wytyczne CISBE (The Chartered Institution of Building Services Engineers), a w Stanach Zjednoczonych standard ASHRAE 55 (American Society of Heating, Refrigerating and Air-Conditioning Engineers). Komfort termiczny jest pojęciem subiektywnym, osobistym odczuciem użytkowników budynków, które zależy od wielu czynników, w tym od rodzaju aktywności, noszonego ubrania, nastroju, czasu i miejsca przebywania, stanu zdrowia a nawet wieku i płci [2]. Zgodnie z definicją brytyjskiej organizacji CISBE „komfort termiczny jest konglomeratem fizjologii, psychologii $i$ kultury. To, co będzie akceptowalne zależy zarówno od rodzaju aktywności i ubioru, jak i temperatury, prędkości powietrza i jego wilgotności" [5]. Natomiast według standardu ASHRAE 55-2013, "komfort termiczny jest stanem umysłu, który polega na zadowoleniu z otoczenia termicznego i podlega subiektywnej ocenie" [3].

Dotychczas przyjmowane wartości parametrów komfortu termicznego, były takie same zarówno dla budynków wyposażonych w mechaniczny system wentylacji i chłodzenia, jak i przewietrzanych w sposób naturalny. Jednak badania przeprowadzone przez Dear i Branger w Stanach Zjednoczonych oraz Nicol i Humphrey [1] w Wielkiej Brytanii pokazują, że w budynkach wyposażonych w naturalny system wentylacji należy przyjmować inny zakres wartości. Użytkownicy takich budynków są częściej skłonni zaakceptować większy zakres tych parametrów szczególnie, jeśli mogą je sami kontrolować. Dlatego w standardzie ASHRAE 55-2013 został przyjęty tzn. adaptacyjny model komfortu termicznego, który został zdefiniowany, jako "model, który odnosi projektowq temperaturę wnętrza albo akceptowany zakres temperatur wnętrza do zewnętrznych parametrów meteorologicznych i klimatycznych" [1]. Powyższy model zakłada, że poziom komfortu termicznego będzie się zmieniał w zależności od klimatu zewnętrznego. Uwzględnia on także kontrolowanie parametrów tego komfortu przez użytkowników oraz ich możliwości adaptacyjne. W modelu adaptacyjnym oczekuje się, że użytkownicy będą ubierali się adekwatnie do panującej na zewnątrz temperatury, czasami oznacza to, że pracownicy będą ubierać się mniej formalnie. Przyjęcie powyższego modelu przez ASHRAE jest nowym podejściem, które przywraca rolę rozwiązań przestrzennych w kształtowaniu klimatu wnętrza. Rola ta została zmarginalizowana od czasu, gdy kształtowanie komfortu termicznego stało się możliwe za pomocą rozwiązań mechanicznych, a zadaniem architekta było jedynie zapewnienie odpowiedniej przestrzeni dla urządzeń wentylacyjnych. Zagadnienia związane z klimatem wewnętrznym pozostawały prawie wyłącznie w gestii projektantów instalacji wentylacji wewnętrznych. W systemach naturalnych, komfort termiczny jest kształtowany jest za pomocą rozwiązań przestrzennych, konstrukcyjnych oraz funkcjonalnych, przy uwzględnieniu warunków zewnętrznych (klimatu, topografii, otoczenia budynku...). Z tego powodu projekt budynku przewietrzanego naturalnie wymaga projektowania zintegrowanego, w którym już od samego początku projektu, biorą udział projektanci różnych branż, w tym architekci, projektanci systemu wentylacji naturalnej, konstruktorzy, inżynierowie przeprowadzający symulacje energetyczne...W budynkach przewietrzanych naturalnie, projektowanie zintegrowane jest konieczne, ponieważ żaden z projektantów sam nie posiada kompetencji, żeby taki budynek zaprojektować. Znalezienie takiego zespołu specjalistów jest trudne, zwłaszcza na rynku krajowym, i jest jedną z przyczyn, która powoduje, że inwestorzy decydują się na zastosowanie w budynku systemu wentylacji mechanicznej. 


\section{Przewietrzanie budynków a oszczędność energii}

Jeszcze do niedawna głównym zadaniem projektu systemu wentylacji naturalnej, było jedynie zaprojektowanie sposobu usuwania zużytego powietrza z budynku. Natomiast nawiew powietrza odbywał się przede wszystkim w sposób niekontrolowany: poprzez nieszczelności w stolarce okiennej i drzwiowej oraz infiltrację przez przegrody zewnętrzne. W sytuacjach czasowego, większego zapotrzebowania na świeże powietrze po porostu otwierano okna. Było to zupełnie inne podejście, niż występujące w budynkach współczesnych, w których dąży się do osiągnięcia jak największej szczelności obudowy zewnętrznej [6]. Współczesne budynki powinny być efektywne energetycznie, a zarówno nawiew jak i wywiew powietrza powinny odbywać się w nich w sposób kontrolowany. Po pierwsze, dlatego że nieszczelności w obudowie zewnętrznej budynku powodują straty ciepła, a po drugie ze względu na dążenie do jak największej efektywności systemu wentylacji, w której strumień świeżego powietrza powinien przepływać w sposób kontrolowany. W dobrze zaizolowanych i szczelnych budynkach, w których zredukowano straty ciepła przez przenikanie i infiltrację, straty ciepła powodowane przez przewietrzanie, mogą przekraczać nawet $50 \%$ sumy całkowitych strat ciepła [7]. Im lepiej ocieplony będzie budynek, tym procentowy udział tych strat, w całkowitym bilansie strat ciepła w budynku, będzie większy. Z powyższych przyczyn, dochodzi czasem do konfliktów pomiędzy tendencją do zmniejszania ilości energii na potrzeby ogrzewania a koniecznością zapewnienia odpowiedniej ilości świeżego powietrza w budynku. Efektem tego konfliktu jest zła jakość powietrza wewnętrznego, która może być przyczyną występowania wielu chorób, co już zostało wspomniane powyżej, oraz zniszczenia konstrukcji budynku, głównie z powodu jej zawilgocenia. Problem ten występuje często np. w poddanych termomodernizacji budynkach mieszkaniowych. W tych budynkach, ocieplenie ścian zewnętrznych i wymiana stolarki okiennej spowodowały znaczne ograniczenie ilości powietrza, która wpływała do budynku w sposób niekontrolowany. Teoretycznie świeże powietrze powinno teraz wpływać przez rozszczelnienie albo otwarcie okien. Jednak obydwie te czynności wymagają działania użytkowników, którzy często, głównie z chęci oszczędzenia energii na potrzeby ogrzewania, ich nie podejmowali. W efekcie, wymiana powietrza w tych budynkach jest niewystarczające do zapewnienia jego odpowiedniej jakości. Obecnie obowiązujące polskie przepisy techniczno-budowlane wymagają stosowania rozwiązań, które zapewnią wymianę powietrza nawet bez udziału użytkowników [8]. Problem zapewnienia odpowiedniej jakości powietrza w budynkach poddawanych termomodernizacji, wystąpił nie tylko w Polsce, ale także w innych krajach. Dlatego np. w Niemczech wprowadzono w 2009 roku nowelizację normy DIN 1946-6, dotyczącej wentylacji mieszkań, zgodnie, z którą do projektu budowlanego należy dołączyć koncepcje systemu wentylacji działającego w czterech trybach: wentylacja zapobiegająca zawilgoceniu konstrukcji, zredukowana wentylacja, wentylacja normowa i intensywna wentylacja, dwa pierwsze tryby pracy nie wymagają udziału użytkownika [9].

Istnieją różne strategie rozwiązania powyższego konfliktu. Rozwiązania szczegółowe przyjęte w tych strategiach, zależą od warunków zewnętrznych, co oznacza, że w klimacie umiarkowanym systemy wentylacji naturalnej powinny pracować w co najmniej trzech scenariuszach: jesienno-wiosennym, zimowym i letnim.

W klimacie umiarkowanym wentylacja naturalna najlepiej działa w okresie jesienno-wiosennym. W tym czasie różnica pomiędzy temperaturami zewnętrznymi i wewnętrznymi jest na tyle duża, że powstała w jej wyniku różnica ciśnień jest $w$ stanie zapewnić oczekiwaną wymianę powietrza. Jednocześnie temperatura powietrza zewnętrznego jest na tyle wysoka, że jego ogrzanie we wnętrzu budynku przez system ogrzewania, nie jest bardziej energochłonne niż wstępne ogrzanie i wtłoczenie powietrza przez system wentylacji mechanicznej. Dodatkowo system rekuperacji, stosowany do odzysku ciepła ze zużytego powietrza, nie działa dobrze przy tak małych różnicach temperatur pomiędzy powietrzem świeżym i zużytym, jakie występują w okresie jesienno-wiosennym. Z tych powodów budynki wyposażone w hybrydowe systemy wentylacji, w okresach przejściowych są najczęściej przewietrzane w sposób naturalny.

Zimą, w związku z dużą różnicą temperatur, a więc i ciśnienia, pomiędzy wnętrzem i zewnętrzem budynku, otwory wentylacyjne muszą zostać zmniejszone, w przeciwnym razie będzie się przez nie odbywać zbyt duża wymiana powietrza, która spowoduje straty ciepła. W tym okresie usuwanie nadmiernych zysków ciepła jest zadaniem wentylacji tylko w tych budynkach, w których są one bardzo duże. Dlatego ilość wpływającego powietrza może zostać zredukowana do takiego minimum, które jest w stanie zapewnić odpowiednią jakość pozostałych parametrów powietrza wewnętrznego (zawartość w powietrzu $\mathrm{CO}_{2}$, usuwanie wilgoci i zanieczyszczeń powietrza). Przy niskich temperaturach zewnętrznych znaczna część energii może zostać odzyskana przez system rekuperacji, a ponieważ w systemie wentylacji naturalnej jest on trudny do zastosowania, bardziej korzystne 
energetycznie może być zastosowanie wentylacji mechanicznej. Jest to jeden z powodów, dla którego inwestorzy decydują się na zastosowanie hybrydowego systemu wentylacji, w którym budynek jest przewietrzany zimą poprzez system mechaniczny z odzyskiem ciepła.

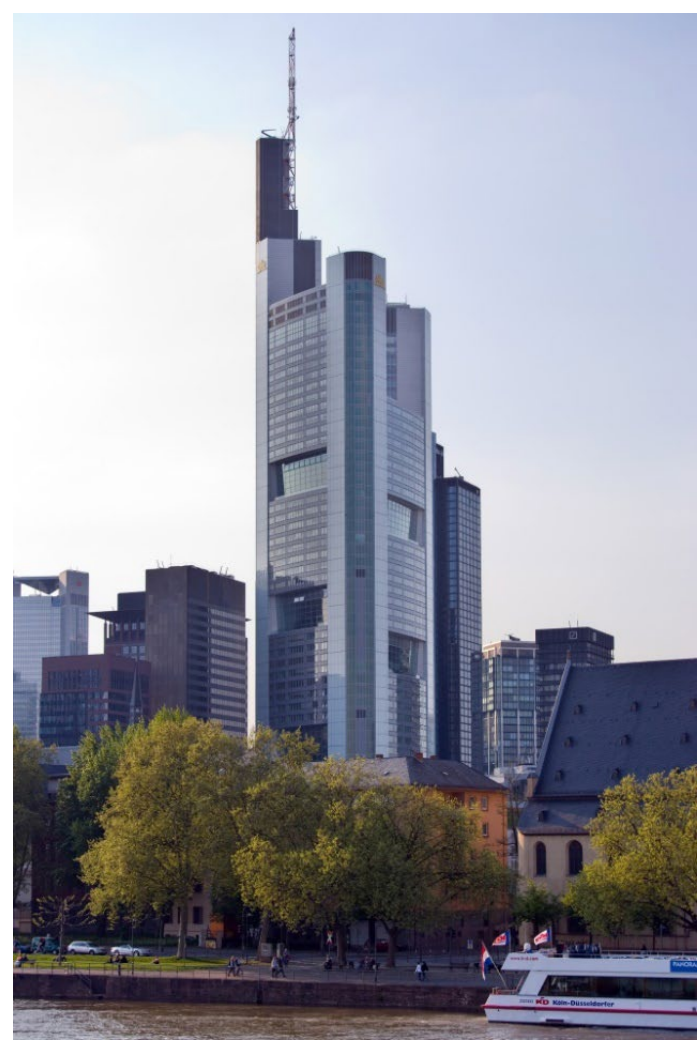

Ryc. 1. Widok budynku Commerzbank we Frakfurcie [9]

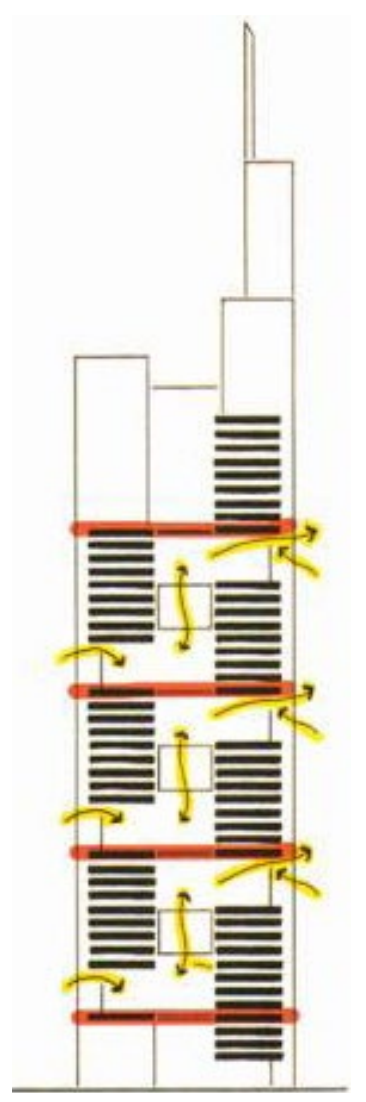

Ryc. 2. Schemat przewietrzania atriów i ogrodow zimowych w budynku Commerzbank we Frakfurcie [10]

Innym rozwiązaniem, które pozwala na uniknięcie strat ciepła powodowanych przez nawiew zimnego powietrza, może być jego wstępne ogrzanie w sposób bierny w strefach buforowych. Takimi strefami buforowymi są podwójne elewacje, atria ogrody zimowe. W przestrzeniach tych gromadzone są solarne zyski ciepła, dzięki czemu ich temperatura jest wyższa niż na zewnątrz budynku, ale niższa niż w pomieszczeniach użytkowych. Powietrze zewnętrzne wpływa najpierw do takiej strefy buforowej, skąd jest nawiewane do pomieszczeń użytkowych. Przykładem budynku, w którym system atriów i ogrodów zimowych jest częścią systemu naturalnego przewietrzania budynku, jest budynek biurowy Commerzbank we Frankfurcie , z 1997 roku, projektu biura Sir Norman Foster and Partners. Poniżej przedstawiono widok tego budynku oraz schemat działania systemu naturalnej wentylacji w jego w atriach i ogrodach zimowych.

Powietrze może być także nawiewane do budynku poprzez kanał nawiewny umieszczony w gruncie albo w innym materiale o stałej temperaturze. Nawiew powietrza może odbywać się w sposób mechaniczny, jak w wielu budynkach współczesnych, albo w sposób naturalny jak w obiektach historycznych.

Latem, gdy temperatury zewnętrzne są wyższe od wewnętrznych, problemem może być zapewnienie działania systemu wentylacji w sposób ciągły, unikanie zewnętrznych zysków ciepła spowodowanych przez nawiewane gorące powietrze oraz usuwanie wewnętrznych zysków ciepła. Inwestorzy często nie mają pewności, czy powyższe problemy mogą zostać rozwiązane jedynie za pomocą biernych sposobów, i czy nie będzie się to wiązać $z$ obniżeniem poziomu komfortu termicznego. Z powyższych powodów decydują się na zastosowanie systemu wentylacji mechanicznej z chłodzeniem, co powoduje konieczność poniesienia kosztów zużycia energii na wentylację i chłodzenie. Z drugiej strony, skuteczność działania systemu wentylacji naturalnej w okresie występowania wysokich temperatur zewnętrznych, jest związana z koniecznością zastosowania zarówno środków 
architektonicznych i konstrukcyjnych, jak i związanych z użytkowaniem obiektu. Decyzja o zastosowaniu niektórych z nich musi zostać podjęta już na etapie projektu.

Po pierwsze przyjmuje się, że system wentylacji naturalnej może zapewnić komfort termiczny tylko wtedy, gdy suma wewnętrznych i zewnętrznych zysków ciepła nie przekracza $30-40 \mathrm{~W} / \mathrm{m}^{2}$ dziennie [5]. Z tego powodu decydując się na przewietrzanie budynku w sposób naturalny, w okresie występowania wysokich temperatur zewnętrznych, w pierwszej kolejności należy dążyć do ograniczenia zysków ciepła. Źródłem zewnętrznych zysków ciepła może być zarówno promieniowanie słoneczne, czyli zyski solarne, jak i nawiewane, gorące powietrze. Analiza sposobów ograniczenia zysków solarnych przekracza ramy tego artykułu, tutaj zostanie tylko wspomniane, że najczęściej stosowanymi metodami są zewnętrzne elementy zacieniające oraz specjalne rodzaje szklenia. Stosując te metody należy zwrócić uwagę na konieczność zapewnienia odpowiedniej ilości światła dziennego i nieograniczanie kontaktu wzrokowego z otoczeniem budynku. Natomiast w celu ograniczenia zysków ciepła od powietrza zewnętrznego, ilość powietrza nawiewanego, jeśli nie zostało ono wcześniej schłodzone, ogranicza się do niezbędnego minimum. Źródłem zysków wewnętrznych są użytkownicy, oświetlenie, urządzenia... Zyski wewnętrzne od oświetlenia i urządzeń, mogą zostać zmniejszone poprzez wykorzystanie oświetlenia naturalnego oraz energooszczędnego oświetlenia sztucznego i energooszczędnych urządzeń. Zyski cieplne od ludzi można zmniejszyć stosując mniejszą gęstość użytkowania.

\section{Chłodzenie naturalne}

Projekt budynku niechłodzonego w sposób mechaniczny, powinien uwzględniać możliwość zapewnienia w nim komfortu termicznego, także w okresach występowania wysokich temperatur zewnętrznych. Poniżej opisano strategie wykorzystywane w systemach naturalnego przewietrzania, dzięki którym temperatura powietrza bądź jej odczucie, mieszczą się w granicach komfortu termicznego.

\section{Obniżenie temperatury nawiewanego powietrza}

W tym przypadku świeże powietrze jest nawiewane poprzez kanały, w których ulega schłodzeniu. Wykorzystuje się przy tym stałą temperaturę gruntu, wody, skał, efekt schładzania poprzez parowanie (schładzanie adiabatyczne), konstrukcje o dużej pojemności cieplnej. Przepływ powietrza i jego nawianie do budynku, mogą się odbywać w sposób mechaniczny, jak w wielu budynkach współczesnych, albo naturalny jak we wszystkich budynkach historycznych.

Poniższy schemat pokazuje zasadę nawiewu świeżego powietrza w willach palladiańskich z rejonu Venetio, w których do nawiewu powietrza do pomieszczeń mieszkalnych i reprezentacyjnych, wykorzystano naturalne kanały powstałe w wyniku zjawisk krasowych [1].

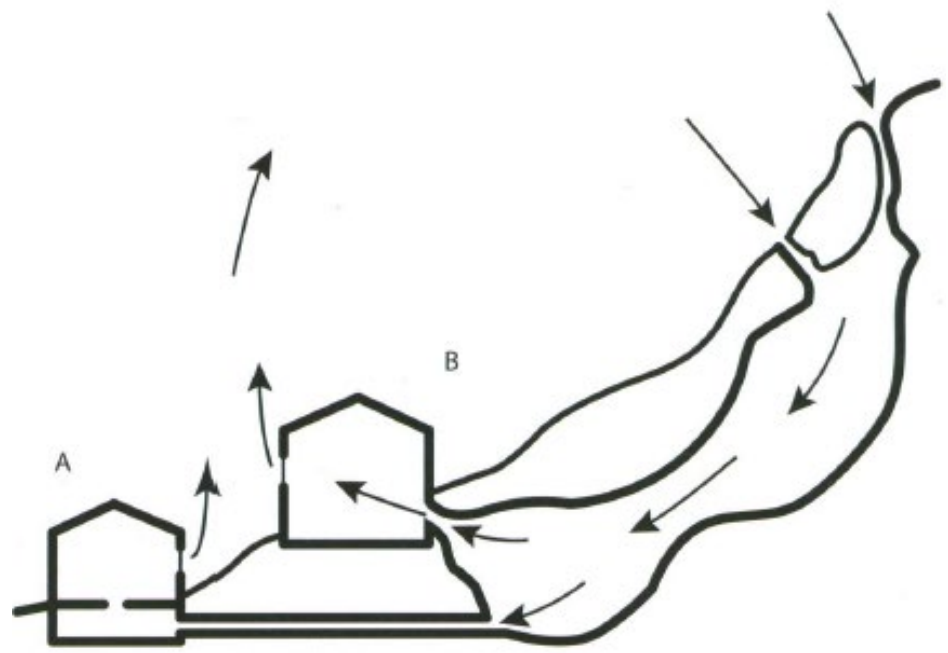

Ryc. 3. Schemat działania systemu naturalnej wentylacji w willach palladiańskich w rejonie Venetio [1] 
W budynku Everyman Theatre w Liverpoolu z roku 2013, projektu Haworth Tompkins, powietrze przed wpłynięciem do przewietrzanej naturalnie widowni, przepływa przez żelbetowy kanał o dużej pojemności ciepInej, gdzie ulega schłodzeniu. Taki system nawiewu ma także tę zaletę, że umożliwia umieszczenie wlotu do kanału, w miejscu o najmniejszym zanieczyszczeniu. W tym przypadku powietrze jest nawiewne do budynku przy wykorzystaniu efektu kominowego, wytwarzanego na widowni. Wystarczająco silny efekt kominowy, jest wytwarzany przez cztery kominy grawitacyjne, oraz zyski ciepła od widowni i umieszczonego w górze pomieszczenia oświetlenia. W przypadku, gdyby system naturalny okazał się niewystarczający, budynek został wyposażony także w system wentylacji mechanicznej z chłodzeniem. Jednak przez w ciągu pierwszych lat eksploatacji teatru, nie wystąpiła konieczność uruchamiania systemu mechanicznego. Powyższy schemat pokazuje zasadę działania tego systemu. [12]

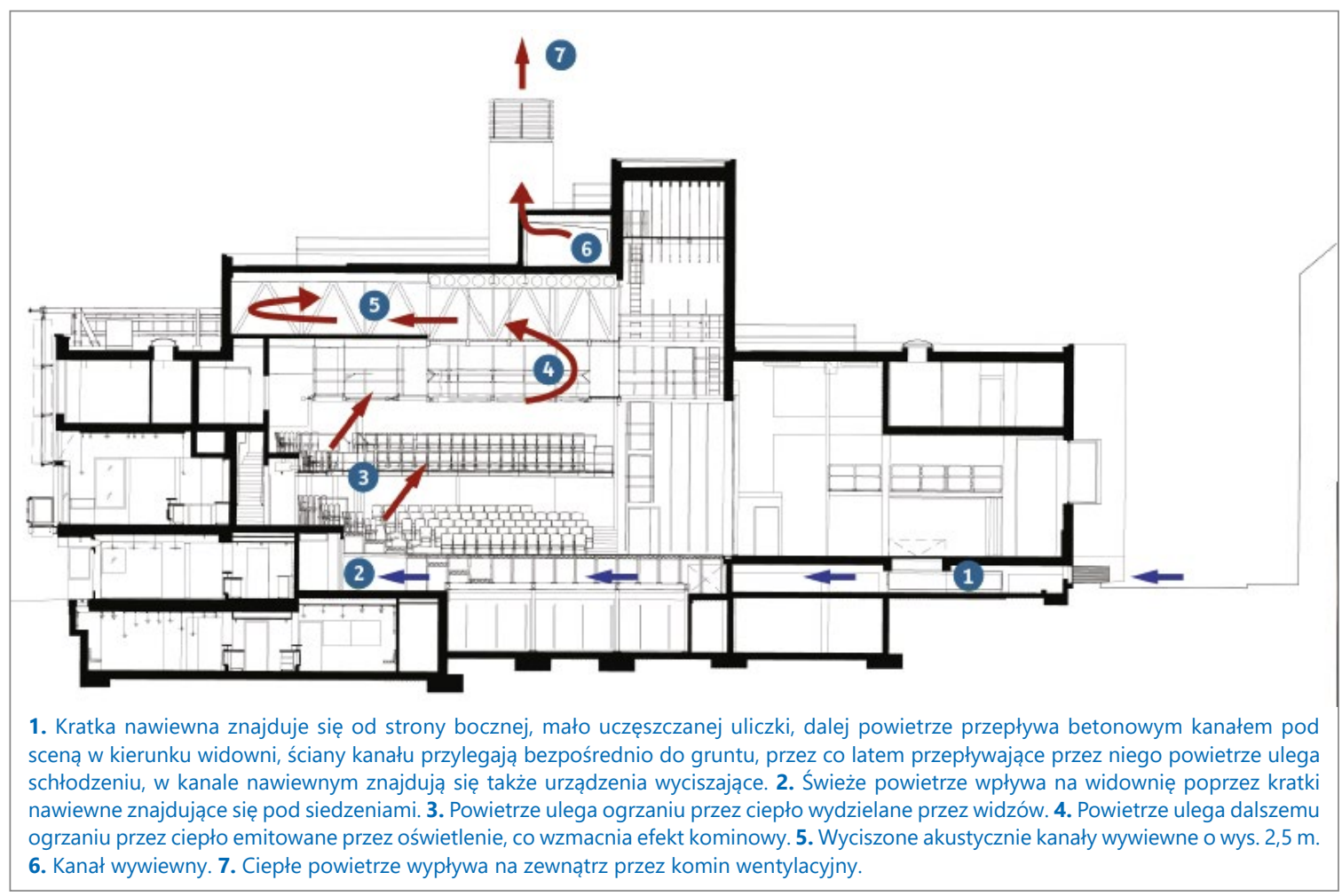

Ryc. 4. Schemat działania systemu naturalnej wentylacji Everyman Theatre w Liverpoolu [12]

Najczęściej w budynkach przewietrzanych jedynie w sposób naturalny, nie zawsze będzie możliwe zapewnienie w sposób ciągły stałych parametrów komfortu termicznego, w tym temperatury powietrza. Nie oznacza to jednak, że ich użytkownicy będą automatycznie odczuwać termiczny dyskomfort, dlatego że odczucie komfortu termicznego jest zjawiskiem złożonym, zależnym od wielu czynników, co już wspomniane wcześniej i wykorzystywane w opisanych poniżej systemach naturalnego chłodzenia.

\section{Obniżenie temperatury powietrza i temperatury odczuwalnej, wykorzystujące dużą pojemność cieplną budynku i nocne chłodzenie}

W systemie wentylacji naturalnej z chłodzeniem nocnym, wykorzystywana jest zdolność budynku do magazynowania zysków ciepła oraz chłodne, nocne powietrze do ich usuwania. Energia pozyskana w ciągu dnia, która nie może być od razu usunięta z budynku, musi zostać zmagazynowana. Energia ta usuwana jest noca, przez przepływające przez budynek chłodne, nocne powietrze. Strumień chłodnego powietrza można wywołać w sposób naturalny albo mechaniczny.

Do magazynowania energii wykorzystuje się elementy budynku o dużej pojemności cieplnej. Są to najczęściej masywne elementy konstrukcyjne budynku np. żelbetowe stropy i słupy, żelbetowe albo murowane 
ściany. Masywna konstrukcja budynku może poprawiać jego komfort termiczny nie tylko, dlatego, że poprzez magazynowanie zysków ciepła może hamować wzrost temperatury powietrza, ale także dlatego, że temperatura odczuwana jest wypadkową temperatury powietrza i elementów otoczenia [2]. Dlatego jeśli, temperatura elementów występujących w pomieszczeniu jest niższa niż jego temperatura powietrza, to temperatura odczuwalna też będzie niższa niż temperatura powietrza.

Jednak nocne chłodzenie związane jest także z ograniczeniami i problemami, które projektanci muszą uwzględnić.

Po pierwsze warunkiem wykorzystania w systemie nocnego chłodzenia elementów budynku o dużej pojemności cieplnej, jest ich wyeksponowanie, tzn. nie mogą one zostać osłonięte elementami wykończenia wnętrz obniżającymi ich pojemność cieplną, np. sufitami podwieszanymi albo płytami drewnianymi. Taka ekspozycja twardych powierzchni obniża komfort akustyczny wnętrza, co często oznacza konieczność wprowadzenia dodatkowych elementów poprawiających jego akustykę. Zdjęcie poniżej pokazuje widok sali teatralnej wspomnianego powyżej budynku Everyman Theatre, w którym do pokrycia ścian użyto cegły rozbiórkowej.

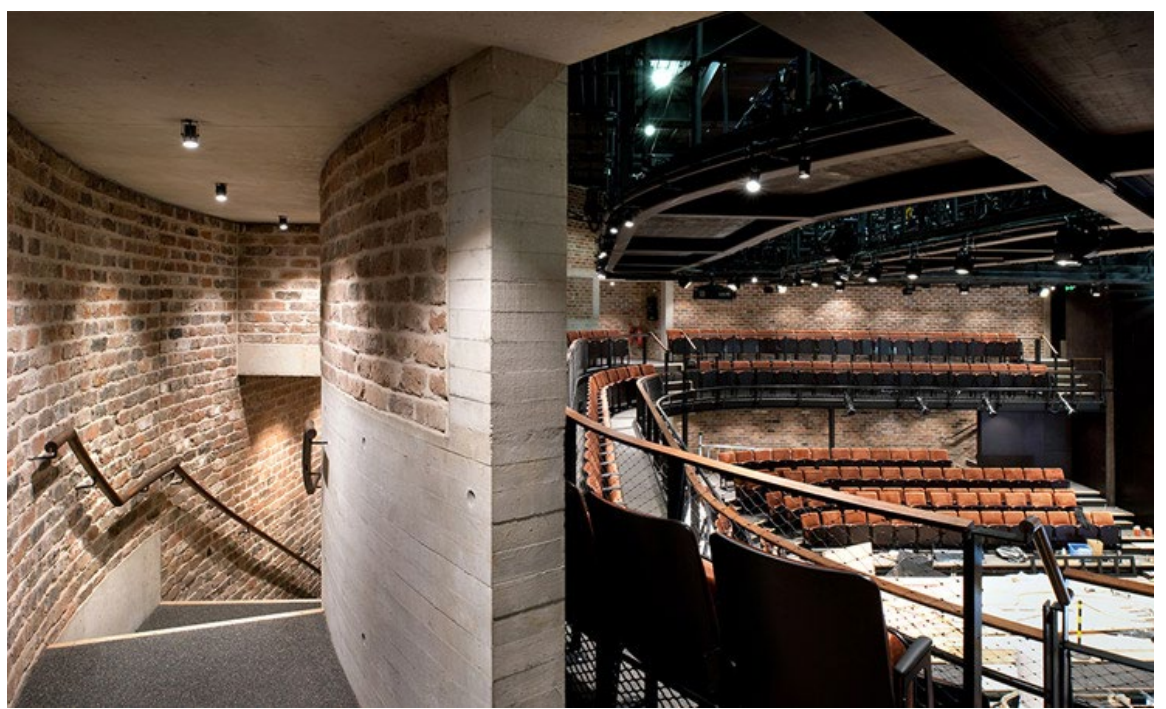

Ryc. 5. Widok wnętrza widowni Everyman Theatre w Liverpoolu [13]

Brak sufitów podwieszanych powoduje konieczność znalezienia alternatywnych możliwości poprowadzenia instalacji w budynku (np. w przestrzeni podniesionej podłogi). Rozwiązaniem pozwalającym ominąć powyższe problemy jest zastosowanie do magazynowania energii materiałów zmieniających swój stan skupienia (PMC - phase change materials).

Po drugie, warunkiem działania nocnego chłodzenia jest występowania niskich temperatur w ciągu nocy. Jednak często w czasie występowania długotrwałych okresów wysokich temperatur, także temperatury nocne nie są wystarczająco niskie, żeby nocne powietrze było w stanie usunąć nadmierne zyski ciepła, zmagazynowane podczas dnia.

Wykorzystanie potencjału nocnego chłodzenia w jak największym stopniu, może czasami oznaczać, że poranne temperatury w pomieszczeniach użytkowych będą znajdować się poniżej temperatur komfortowych.

\section{Obniżenie odczuwalnej temperatury wykorzystujące zwiększoną prędkość powietrza}

Wzrost prędkości powietrza powoduje, że temperatura odczuwalna jest niższa niż temperatura powietrza [5]. Zjawisko to jest przyczyną tego, że w okresie występowania niskich temperatur zewnętrznych wiatr obniża jeszcze temperaturę odczuwalną, ale w okresie występowania wysokich temperatur, może zostać wykorzystane do poprawienia komfortu termicznego we wnętrzu budynku. Prędkość powietrza wynosząca ok. 0,25 m/s powoduje, że temperatura odczuwalna jest niższa niż temperatura powietrza o ok. $1 \mathrm{~K}$, a prędkość wynosząca ok. 0,55 m/s obniża temperaturę odczuwalną o ok. 2K [5]. Zwiększenie prędkości powietrza w budynkach przewietrzanych naturalnie nawet do $1,2 \mathrm{~m} / \mathrm{s}$ dopuszcza adaptacyjny model komfortu termicznego [1]. 


\section{Zmiana oczekiwań użytkowników dotyczących poziomu komfortu termicznego w długich okresach występowania wysokich temperatur zewnętrznych}

Badania dotyczące oczekiwanego poziomu komfortu termicznego pokazały, że oczekiwania użytkowników zmieniają się podczas długotrwałego występowania wysokich temperatur zewnętrznych. Oznacza to, że użytkownicy akceptują wtedy wyższe temperatury wewnętrzne i nie powoduje to ich odczucia dyskomfortu [5].

\section{Ograniczenia wynikające z zastosowania wentylacji i chłodzenia naturalnego}

Przewietrzanie budynku w sposób naturalny wymaga zastosowania odpowiednich rozwiązań przestrzennych, funkcjonalnych i materiałowych. Często wiąże się także z koniecznością zainwestowania większych nakładów finansowych na początku inwestycji, w porównaniu do budynków wyposażonych jedynie w system wentylacji mechanicznej. A w niektórych przypadkach w ogóle nie jest możliwe przewietrzanie budynku jedynie w sposób naturalny.

Poniżej zamieszczono listę wad i ograniczeń systemów wentylacji naturalnej.

- Wentylacja naturalna nie zawsze jest w stanie zapewnić w sposób ciągły oczekiwane parametry powietrza, np. jego wilgotność $\mathrm{i}$ temperaturę. $Z$ tego powodu raczej nie stosuje się jej w budynkach lub pomieszczeniach, w których parametry te muszą zostać zachowane (np. sale operacyjne, archiwa...). Natomiast stosowanie jej w innych budynkach, często wymaga odejścia od paramentów komfortu termicznego właściwych dla budynków wyposażonych w system wentylacji mechanicznej z chłodzeniem, i zastosowanie tzn. „adaptacyjnego modelu komfortu". Z tego powodu wielu inwestorów wyposaża budynki w systemy hybrydowe, w których wentylacja mechaniczna włącza się wtedy, gdy naturalna nie jest w stanie zapewnić oczekiwanego poziomu komfortu termicznego.

- Nawet w budynkach przewietrzanych naturalnie, występują pomieszczeniach, w których poziom zysków ciepła, ilości pary wodnej, emisji $\mathrm{CO}_{2}$, albo innych szkodliwych substancji, przekracza możliwości ich usunięcia za pomącą wentylacji naturalnej, np. serwerownie, sale konferencyjne, pomieszczenia higieniczno-sanitarne...Pomieszczenia te są przewietrzane i w razie potrzeby także chłodzone w sposób mechaniczny.

- Prędkość wpływającego do budynku świeżego powietrza zależy m.in. od otoczenia budynku (zabudowy, topografii, występującej roślinności), i w intensywnej miejskiej zabudowie może być niewystarczająca do zapewnienia skutecznej wentylacji naturalnej.

- Stosowanie wentylacji hybrydowej powoduje konieczność poniesienia kosztów i zajęcia powierzchni pod dwa systemy wentylacyjne, wentylacji naturalnej i mechanicznej.

- Przewietrzanie naturalne wymaga zastosowania takich rozwiązań przestrzennych i konstrukcyjnych, które powodują większe koszty inwestycyjne (atria, ogrody zimowe, podwójne elewacje, masywna konstrukcja, wyższa wysokość pomieszczeń...), niż w przypadku budynków przewietrzanych i chłodzonych mechanicznie. Pomimo, że koszty te zostaną zrekompensowane przez oszczędności związane z mniejszym zużyciem energii na potrzeby wentylacji, to powodują one, że wielu inwestorów nie decyduje się na zastosowanie systemu wentylacji naturalnej.

- Z jednej strony, zastosowanie przewietrzania naturalnego daje możliwość oszczędzenia powierzchni zajmowanej przez urządzenia wentylacyjne w systemie wentylacji mechanicznej, jednak z drugiej strony wymaga zwiększenia wysokości pomieszczeń i przeznaczenia powierzchni pod ogrody zimowe, podwójne elewacje, atria, kominy i inne rozwiązania przestrzenne wchodzące w skład systemu wentylacji naturalnej.

- Najczęściej system przewietrzania naturalnego powoduje konieczność zastosowania płytszych traktów, niż w budynkach z systemem wentylacji mechanicznej.

- Różnica ciśnień w systemie wentylacji naturalnej i wynikająca z niej prędkość przepływu powietrza są niewielkie, dlatego należy unikać stosowania na drodze przepływu strumienia powietrza jakichkolwiek przeszkód mogących tę różnicę jeszcze obniżyć. Z tego powodu, w systemach wentylacji naturalnej praktycznie niemożliwe jest stosowanie filtrów oczyszczających. Stanowi to ograniczenie w stosowaniu wentylacji naturalnej w budynkach zlokalizowanych w miejscach, w których występują zanieczyszczenie powietrza (np. przy ruchliwych trasach komunikacyjnych).

- Zmniejszenie, wspomnianej powyżej, niewielkiej różnicy ciśnień, powodują także wszelkie elementy aranżacji wnętrz stojące na drodze przepływu strumienia powietrza, a zwłaszcza te o wysokości całej 
kondygnacji np. meble biurowe, ściany działowe. $Z$ tego powodu w budynkach przewietrzanych naturalnie, preferowaną formą aranżacji wnętrza są pomieszczenia jednoprzestrzenne lub wielokondygnacyjne, bez ścian działowych, albo tylko z lekkim przepierzeniem, np. biura typu "open space”, otwarte atria, połączenie przestrzeni komunikacyjnej i miejsc pracy. Użytkownicy tych pomieszczeń często narzekają na niski poziom komfortu akustycznego i brak możliwości skupienia się, i to nawet po zastosowaniu elementów wyposażenia wnętrza, które pochłaniają dźwięk.

- Eksponowanie twardych elementów konstrukcyjnych o dużej pojemności cieplnej, wykorzystywanych w systemie nocnego chłodzenia, powoduje, podobnie jak opisane powyżej stosowanie dużych, otwartych pomieszczeń, obniżenie poziomu komfortu akustycznego. Z tego powodu, czasami zamiast eksponować twarde betonowe powierzchnie stosuje się sufity podwieszane i elementy PCM.

- System nocnego chłodzenia będzie spełniał swoją rolę tylko wtedy, gdy wewnątrz budynku zostanie zmagazynowane wystarczająca ilość chłodu. Oznacza to, że temperatury nocne podczas występowania wysokich temperatur w ciągu dnia, muszą być na tyle niskie, żeby było to możliwe. Jednak często w ciągu długotrwałych okresów występowania wysokich temperatur, temperatury nocne nie są wystarczająco niskie. Wtedy temperatura w budynku, może znajdować się powyżej poziomu komfortu.

- Schłodzenie konstrukcji budynku nocą, czasami powoduję, że temperatura wnętrza w godzinach porannych może znajdować się poniżej poziomu komfortu.

- Konieczność projektowania zintegrowanego, niejasne podziały kompetencyjne pomiędzy projektantami poszczególnych branż i trudności ze znalezieniem specjalistów będących w stanie zaprojektować budynek przewietrzany naturalnie.

Powyższe ograniczenia i trudności związane z naturalnymi systemami przewietrzania budynków, powodują, że pomimo zalet tych systemów, inwestorzy jednak często decydują się na mechaniczny system wentylacji.

\section{Literatura}

[1] Passe U., Battaglia F. Designing Spaces for Natural Ventilation An Architect's Guide, Taylor \&Francis, New York 2015.

[2] Hegger, Fuchs, Stark, Zeumer, Energy Manual - Sustanable Architecture, Birkhauser Verlag AG, Basel, Boston, Berlin 2008.

[3] Wood A., Salib R., Natural Ventilation in High-Rise Office Buildings, CTBUH Technical Guide, Routledge, New York, London 2013.

[4] Halliday S., Sustainable Construction, Butterworth-Heinenmann, Oxford Haselbach L 2008.

[5] Natural ventilation in non-domestic building CIBSE Application Manual AM10, The Charted Institution of Building Services Engineers, London 2005.

[6] http://www.iea.org/publications/freepublications/publication/ TechnologyRoadmapEnergyEfficientBuildingEnvelopes z dn.21.02.2015.

[7] Environmental design CISBE Guide A, The Chartered Institution of Building Services Engineers, London 2015

[8] Rozporządzenie Ministra Infrastruktury w sprawie warunków technicznych, jakim powinny odpowiadać budynki i ich usytuowanie z dnia 12 kwietnia 2002 r. (Dz.U. Nr 75, poz. 690)

[9] http://www.energieagentur.nrw/lueftung dostęp z dn. 25.02.2015.

[10] https://en.wikipedia.org/wiki/Commerzbank_Tower dostęp z dn.06.04.2016.

[11] http: //cmiserver.mit.edu/ natvent/Europe/ commerzbank.htm dostęp z dn.06.04.20116.

[12] http://www.cibsejournal.com/case-studies/leading-man/ dostęp z dn.03.10.2016.

[13] http://www.haworthtompkins.com/built/proj44/index.html dostęp z dn.07.10.2016. 


\title{
Natural Ventilation and Thermal Comfort in Public Buildings
}

\begin{abstract}
Indoor air quality and building's thermal comfort depend very much on a ventilation system. At the same time they have an influence on health and well- being of users of buildings. The users prefer the natural ventilated spaces. The running costs of naturally ventilated buildings are smaller than the running costs of mechanically ventilated buildings. However, the construction costs of the naturally ventilated buildings could be bigger. Public buildings could be ventilated naturally, but the natural ventilation has its limits. The main rule for designing the natural ventilated spaces is to minimize the heats gains and indoor air pollution, and to expose the hygroscopic building's components and the components with the high thermal capacity.

The temperature and the other air quality components would be more variable in naturally ventilated buildings than in air conditioned buildings. This is the reason, why the natural ventilation rather cannot be used in the buildings and the buildings parts, where the indoor climate parameters have to be constant. The thermal comfort in the naturally ventilated buildings should be assessed by the adaptive comfort model. The adaptive comfort model, relates indoor climate parameters to the outdoor conditions, and take into account the adaptation capacity of the users. The ventilation systems in the buildings located in moderate climates has to work at least in three scenarios: spring-autumn, winter and summer. The natural ventilation systems the best work in spring-autumn scenario. Winter scenario has to take into account the heat losses caused by the intake air. In summer, it could be difficult to maintain the continuity of the natural ventilation and to preserve the building from overheating. The night cooling could be used in periods of the occurring of the high outside temperatures. The effectiveness of the night cooling depends on the limitation of the heat loads, the building's thermal mass and the night air temperature.

The natural ventilation systems require integrated planning. From the very beginning, architects, structure engineers, HVAC designers and the other specialists should work together on the design of the naturally ventilated building. This requirement, the limitations of the natural ventilation and the higher construction costs are the reasons why investors oft prefer the air condition or mixed mode systems.
\end{abstract}

Keywords: natural ventilation, thermal comfort, public buildings, energy efficiency, night cooling, ventilation strategies, thermal mass. 